\title{
INFLUENCE OF CARVEDILOL ON SUPEROXIDE GENERATION AND ENZYME RELEASE FROM STIMULATED HUMAN NEUTROPHILS
}

\author{
Tatiana Mačičkováa, Jana Pečivováa , Radomír Nosálaa, Dagmar Holomáňováb
}

\author{
a Institute of Experimental Pharmacology, Slovak Academy of Sciences \\ b National Transfusion Service, Bratislava, Slovak Republic \\ e-mail: tatiana.macickova@savba.sk
}

Received: June 10, 2005; Accepted: September 25, 2005

Key words: Carvedilol/Human neutrophils/Superoxide generation/Myeloperoxidase

Activation of neutrophils induces generation of reactive oxygen species and release of granule enzymes, which not only participate in the bactericidal mechanisms of these cells, but also in possible tissue damage. We studied the effect of carvedilol (CARV) [0.1-100 $\mu \mathrm{mol} / 1]$, an antihypertensive and cardiovascular drug with antioxidative properties, on superoxide generation (SO) and myeloperoxidase (MPO) release from isolated human neutrophils stimulated with fMLP, a specific receptor activator, or with PMA, a receptor bypassing stimulus. Unstimulated cells showed neither SO formation nor MPO release after preincubation with drug. CARV decreased fMLP and PMA stimulated MPO release and SO generation dose dependently. The inhibitory effect of CARV may attributed to non-specific action since its effect was not influenced by the type of stimulation. It might inhibit SO generation as well as MPO release either by membrane-operating stimulus (fMLP) or membrane bypassing activator (PMA).

\section{INTRODUCTION}

Carvedilol (CARV), [1-[carbazolyl-(4)-oxy]-3-[(2-methoxy-phenoxyethyl)amino]-2-propanol] is a multiple action antihypertensive drug with nonselective $\beta$-adrenergic and selective $\alpha$-adrenergic blocking activity. CARV has been shown to possess antioxidant and free radical scavenging activities, which may contribute to its cardioprotective efficacy ${ }^{1-4}$. The antioxidant activity of CARV has been evaluated and characterised in detail in a variety of in vitro test systems and in a broad spectrum of animal models of myocardial infarction ${ }^{1,3-5}$.

Neutrophils represent the most important source of free radicals and actively contribute to damage of the vessel wall in cardiac and cerebrovascular diseases ${ }^{6}$. Activation of neutrophils induces generation of reactive oxygen species and release of granule enzymes, which not only participate in the bactericidal mechanisms of these cells, but also in possible tissue damage ${ }^{7}$. Dandona et al ${ }^{8}$ described the inhibitory effect of CARV on SO anion release from activated neutrophils ex vivo. CARV was also found to inhibit luminol-enhanced chemiluminescence of reactive oxygen species in blood cells in vitro ${ }^{9}$.

In this work we studied the effect of CARV on the first member of the chain of oxygen species - superoxide anion (SO) and on myeloperoxidase (MPO) release by human neutrophils stimulated with $\mathrm{N}$-formyl-methionyl-leucylphenylalanine (fMLP), a specific receptor activator, or with phorbol-12-myristate-13-acetate (PMA), a receptor bypassing stimulus.

\section{MATERIAL AND METHODS}

\section{Material}

Carvedilol was supplied by La Roche (Mannheim); Dextran T500 (Pharmacia Fine Chemicals); Lymphoprep (Nycomed Pharma AS); PMA (phorbol-12-myristate-13acetate) and fMLP (formyl-methionyl-leucyl-phenylalanine) from Sigma-Aldrich; cytochalasin B (Merck). All other chemicals used were of analytical grade.

The stock solution of carvedilol tartrate was diluted freshly before each experiment with deionised water to the desired concentrations.

\section{Isolation of neutrophils}

Neutrophils were isolated from blood of healthy volunteers into $3.8 \%$ trisodium citrate dihydrate (9:1). After dextran sedimentation and centrifugation on Lymphoprep by modified Boyum's method ${ }^{10}$, neutrophils were resuspended in calcium-, magnesium-free phosphate buffer saline (PBS) solution (in mmol: $137 \mathrm{NaCl}, 2.7 \mathrm{KCl}, 8.1$ $\mathrm{Na}_{2} \mathrm{HPO}_{4}, 1.5 \mathrm{KH}_{2} \mathrm{PO}_{4}$ ), $\mathrm{pH} 7.4$ and washed once with PBS. For individual assays neutrophils were diluted as described below. The purity of isolated neutrophils was $>96 \%$ (light microscopy).

\section{Superoxide determination}

Suspension of neutrophils $\left(10^{6}\right.$ cells $/ 1.5 \mathrm{ml}$ PBS with $1.8 \mathrm{mmol} / 1 \mathrm{CaCl}_{2}$ and $0.5 \mathrm{mmol} / 1 \mathrm{MgCl}_{2}$ ) was preincubated for $5 \mathrm{~min}$ at $37{ }^{\circ} \mathrm{C}$ with carvedilol (0.1-100 $\left.\mu \mathrm{mol} / \mathrm{l}\right)$ and then stimulated with fMLP $(0.1 \mu \mathrm{mol} / 1)$ for $3 \mathrm{~min}$ or with PMA ( $1 \mu \mathrm{mol} / 1)$ for $15 \mathrm{~min}$ at $37^{\circ} \mathrm{C}$. Controls were 
included for the effect of each stimulus and of carvedilol on cytochrome c reduction. Superoxide formation was measured in isolated human neutrophils as superoxide dismutase inhibitable reduction of cytochrome c (ref. ${ }^{11}$ ). The absorbance at $550 \mathrm{~nm}$ was measured using a spectrophotometer Hewlett Packard 8452 A.

\section{Enzyme determination}

For myeloperoxidase (MPO) determination, neutrophils were preincubated with cytochalasin B $(5 \mu \mathrm{g} / \mathrm{ml})$ at room temperature for $5 \mathrm{~min}$. Subsequently the suspension of neutrophils $\left(2 \times 10^{6}\right.$ cells/ml PBS $)$ was incubated with carvedilol $(0.1-100 \mu \mathrm{mol} / 1)$ for $5 \mathrm{~min}$ at $37{ }^{\circ} \mathrm{C}$ and then stimulated with fMLP $(0.1 \mu \mathrm{mol} / 1)$ for $3 \mathrm{~min}$ or with PMA $(1 \mu \mathrm{mol} / 1)$ for $15 \mathrm{~min}$ at $37^{\circ} \mathrm{C}$. Controls for direct interaction of carvedilol and MPO were included. The activity of MPO was assayed in the supernatant after centrifugation $2000 \times \mathrm{g}$ for $10 \mathrm{~min}$ at $4{ }^{\circ} \mathrm{C}$ by determining the oxidation of o-dianisidine in the presence of hydrogen peroxide in a Hewlett Packard 8452 A spectrophotometer at $463 \mathrm{~nm}^{12}$.

\section{Statistical analysis}

All values are given as means \pm SEM. Statistical significance of differences between means was established by Student's t-test and $\mathrm{p}$ values below 0.05 were considered statistically significant.

\section{RESULTS AND DISCUSSION}

Superoxide ( $\mathrm{SO}$ ) radical generated during oxidative burst by neutrophil NADPH oxidase, a precursor of other reactive oxygen species used for host defense against bacterial and fungal pathogens, but they also inflict damage on adjacent tissue, and are thought to be of pathogenic significance in a large number of diseases ${ }^{13}$. Proteolytic enzymes released from activated neutrophils in the process of degranulation have been recognised as an important factor contributing to neutrophil-mediated tissue injury.

CARV is an antihypertensive agent with several mechanisms of antiarrhythmic and antiischaemic activities, underlying its cardio- and cerebroprotective ${ }^{14,15}$ as well as antioxidant properties. The antioxidant action may be relevant for preserving myocardial viability, particularly during ischaemia and reperfusion, conditions linked to the occurrence of oxidative stress ${ }^{1-3,16}$. Ischaemia and reperfusion are potent stimuli for eliciting cardiomyocyte apoptosis, with neutrophils involved in the development of myocardial injury. CARV (at a dose range 1-10 nmol/1) significantly prevented activated neutrophil-induced cardiomyocyte apoptosis on cultured primary neonatal rat cardiomyocytes, possibly due to its antioxidant properties ${ }^{17}$. CARV inhibited oxidative stress in neutrophils and mononuclear cells in patients with hypertension ${ }^{18}$ and exerted a marked scavenger effect on free radical generation-induced red blood cell membrane damage ${ }^{19}$.

CARV inhibits luminol-enhanced chemiluminiscence of reactive oxygen metabolites in vitro. Nosál' et al. ${ }^{9}$ found
Table 1. Effect of carvedilol on fMLP $(0.1 \mu \mathrm{mol} / 1,3 \mathrm{~min} /$ $37^{\circ} \mathrm{C}$ ) stimulated superoxide generation and myeloperoxidase release in human neutrophils

\begin{tabular}{|c|c|c|}
\hline $\begin{array}{c}\text { Carvedilol } \\
(\mu \mathrm{mol} / 1)\end{array}$ & $\begin{array}{c}\text { Superoxide } \\
\text { generation } \\
(\%)\end{array}$ & $\begin{array}{c}\text { Myeloperoxidase } \\
\text { release } \\
(\%)\end{array}$ \\
\hline 0 & 100 & 100 \\
\hline 0.1 & $95.39 \pm 7.52$ & $95.14 \pm 5.70$ \\
\hline 1 & $96.32 \pm 7.28$ & $97.69 \pm 5.30$ \\
\hline 10 & $89.03 \pm 5.71$ & $80.67 \pm 6.00 *$ \\
\hline 100 & $84.08 \pm 2.99 * * *$ & $72.88 \pm 9.30 *$ \\
\hline
\end{tabular}

Values are expressed as percentage of control values obtained after stimulation with FMLP. Each value represents mean from 6-8 experiments \pm SEM. ${ }^{*} \mathrm{p}<0.05, * * * \mathrm{p}<0.001$ as compared to control values without carvedilol

Table 2. Effect of carvedilol on PMA ( $1 \mu \mathrm{mol} / 1,15 \mathrm{~min} /$ $37{ }^{\circ} \mathrm{C}$ ) stimulated superoxide generation and myeloperoxidase release in human neutrophils

\begin{tabular}{|c|c|c|}
\hline $\begin{array}{c}\text { Carvedilol } \\
(\mu \mathrm{mol} / \mathrm{l})\end{array}$ & $\begin{array}{c}\text { Superoxide } \\
\text { generation } \\
(\%)\end{array}$ & $\begin{array}{c}\text { Myeloperoxidase } \\
\text { release } \\
(\%)\end{array}$ \\
\hline 0 & 100 & 100 \\
\hline 0.1 & $99.65 \pm 4.75$ & $102.36 \pm 3.35$ \\
\hline 1 & $93.17 \pm 6.46$ & $97.16 \pm 53.41$ \\
\hline 10 & $87.53 \pm 8.02$ & $91.27 \pm 5.56$ \\
\hline 100 & $70.24 \pm 4.45 * * *$ & $62.04 \pm 4.84 * * *$ \\
\hline
\end{tabular}

Values are expressed as percentage of control values obtained after stimulation with PMA. Each value represents mean from 6-9 experiments \pm SEM. ${ }^{* * *}$ p $<0.001$ as compared to control value without carvedilol

that in the cell-free system CARV dose-dependently decreased chemiluminiscence in the following range of order of radicals: hydroxyl radicals > hydrogen peroxide > superoxide radical. CARV also dose-dependently inhibited chemiluminiscence of isolated human neutrophils in the ranging order of stimuli: A $23187>\mathrm{OpZ}>\mathrm{fMLP}$. Dandona et al. ${ }^{8}$ demonstrated that CARV in patients who were given this drug significantly inhibited $\mathrm{SO}$ generation by neutrophils and mononuclear cells via chemiluminiscence with fMLP stimulation. 
Åsbrink et al..$^{20}$ observed that CARV dose dependently modulated generation of SO ions by NADPH oxidase when induced by fMLP or PMA.

In the present work, we studied the effect of CARV on SO generation and MPO release by human neutrophils stimulated with fMLP, a specific receptor activator, or with PMA, a receptor bypassing stimulus. In every experiment we used parallel incubation of unstimulated controls. These cells showed neither SO formation nor enzyme release after preincubation with CARV. Table 1 illustrates the effect of CARV $(0.1,1,10$ and $100 \mu \mathrm{mol} / 1)$ on fMLP activated SO generation in isolated human neutrophils. CARV inhibited dose-dependently SO generation. In the concentration $100 \mu \mathrm{mol} / 1$, CARV significantly inhibited SO generation to $84.08 \pm 2.99 \%$.

CARV suppressed superoxide generation of human neutrophils stimulated with PMA, as determined by MCLA-dependent chemiluminiscence ${ }^{21}$. The ability of CARV to prevent cell damage and death of activated neutrophils may be due to its property to scavenge SO ions and to inhibit the production of SO radicals by neutrophils. In a concentration-dependent manner. CARV was demonstrated to inhibit the production and generation of SO ions by neutrophils, based on direct measurement of SO release from PMA activated human neutrophil, or its generation during autooxidation of dihydroxyfumaric $\operatorname{acid}^{2,3}$.

In our experimental conditions, we observed that the effect of CARV $(0.1,1,10$ and $100 \mu \mathrm{mol} / 1)$ on PMA activated SO generation in isolated human neutrophils was dose-dependent (Table 2). CARV in the concentration $100 \mu \mathrm{mol} / 1$ significantly decreased SO generation to 70.21 $\pm 4.45 \%$.

The haeme-containing enzyme myeloperoxidase (MPO) is a major constituent of the azurophilic cytoplasmic granules of neutrophils, which is gradually released either intracellulary into the formed phagocytes or extracellulary upon stimulation of cells. Together with the membraneous NADPH oxidase, MPO is involved in the formation of reactive oxygen species and oxidation of biological material. CARV inhibited MPO activity of the cellfree system in a concentration-dependent manner'. CARV treatment reduced MPO levels at both the area-at-risk and the necrotic zone in the ischaemic myocardium ${ }^{22}$.

In our experiments, CARV $(0.1,1,10$ and $100 \mu \mathrm{mol} / 1)$ dose-dependently decreased MPO release from isolated human neutrophils. Incubation of neutrophils with CARV ( 10 and $100 \mu \mathrm{mol} / \mathrm{l}$ ) caused significant inhibition of 80.69 $\pm 6.00 \%$ and $72.88 \pm 9.30 \%$ in MPO release induced by fMLP (Table 1). In the case of PMA stimulated human neutrophils we observed an inhibitory effect of CARV on MPO release in the concentration 1,10 and $100 \mu \mathrm{mol} / 1$, in concentration-dependent manner. In the concentration $100 \mu \mathrm{mol} / \mathrm{l} \mathrm{CARV}$ significantly inhibited MPO release to $62.04 \pm 4.84 \%$ (Table 2).

Our results showing that CARV inhibited SO generation as well as MPO release both by membrane-operating stimulus (fMLP) and by or membrane bypassing activator
(PMA) lead to the conclusion that the inhibitory effect may be attributed to its non-specific action.

Inhibition of SO generation by CARV in stimulated human neutrophils is not only able to reduce the toxicity caused by SO itself, but also, even more importantly, to prevent the formation of higher reactive and toxic hydroxyl radical, and thus to protect against further damage induced by the oxygen-radical chain reactions.

\section{ACKNOWLEDGEMENT}

This work was supported in part by scientific grants APVT-51-029602 and VEGA 2/4003/04.

\section{REFERENCES}

1. Yue TL, Cheng HY, Lysko PG, McKenna PJ, Davis LL, Feuerstein GZ. (1992) Carvedilol, a new vasodilator and $\beta$-adrenoceptor antagonist, is an antioxidant and free radical cavenger. J Pharmacol Exp Ther 263, 92-8.

2. Yue TL, McKenna PJ, Ruffolo RR, Jr, Feuerstein G. (1992) Carvedilol, a new $\beta$ - adrenoceptor antagonist and vasodilator antihypertensive drug, inhibits superoxide release from human neutrophils. Eur J Pharmacol 214, 277-80.

3. Feuerstein GZ, Yue TL, Cheng HY, Ruffolo RR, Jr. (1993) Myocardial protection by the novel vasodilating beta - blocker, carvedilol: Potential relevance of anti - oxidant activity. J Hypertension 11, 41-8.

4. Ruffolo RR, Jr, Feuerstein GZ. (1997) Pharmacology of carvedilol: Rationale for use in hypertension tension, coronary artery disease and congestive heart failure. Cardiovacs Drug Rev 11, 247-56.

5. Cheng J, Kamiya K, Kodama I. (2001) Carvedilol: Molecular and cellular basis for its multifaced therapeutic potential. Cardiovacs Drug Rev 19, 152-71.

6. Feuerstein GZ, Bril A, Ruffolo RR, Jr. (1997) Protective effect of carvedilol in the myocardium. Amer J Cardiol 80, 41-5.

7. Smith JA. (1994) Neutrophils, host defense and inflammation: A double edged sword. J Leukoc Biol 56, 672-86.

8. Dandona P, Karne R, Ghanim M, Hamouda W, Aljada A, Magsino G Jr. (2000) Carvedilol inhibits reactive oxygen species generation by leukocytes and oxidative damage to amino acids. Circulation $101,122-24$.

9. Nosál' R, Jančinová V, Číž M, Drábiková K, Lojek A, Fábryová V. (2005) Inhibition of chemiluminescence by carvedilol in the cell-free system, whole human blood and blood cells. Scand J Clin Lab Invest 65, 55-64

10. Boyum A. (1968) Isolation of mononuclear cells and granulocytes from human blood. Scand J Clin Lab Invest 21, 77-90.

11. Babior BM, Kipnes RS, Curnutte JT. (1973) Biological defense mechanisms. The production by leukocytes of superoxide, a potential bactericidal agent. J Clin Invest 52, 741-4.

12. Somersalo K, Salo OP, Bjorksten F, Mustakalio KK. (1990) A simplified Boyden chamber assay for neutrophil chemotaxis based on quantitation of myeloperoxidase. Anal Biochem 185, 238-42.

13. Babior BM. (2000) Phagocytes and oxidative stress. Am J Med 109, 33-44.

14. Ruffolo RR Jr., Gellai M, Hieble JP, Willette RN, Nichols AJ. (1990) The pharmacology of carvedilol. Eur J Clin Pharmacol 38, 82-8.

15. Savitz SI, Erhardt JA, Anthony JV, Guypta G, Li X, Barone FC, Rosenbaum DM. (2000) The novel $\beta$-blocker, carvedilol provides neuroprotectionin transient focal stroke. J Cereb Blood Flow Metab 8, 1197-204.

16. Ma Xl, Yue TL, Lopez BL, Barone FC, Christopher TA, Ruffolo RR Jr., Feuerstein GZ. (1996) Carvedilol, a new beta adrenorecep- 
tor bloker and free radical scavenger, attenuates myocardial ischaemia-repefusion injury in hypercholesterolemic rabbits. J Pharmacol Exp Ther 277, 128-36.

17. Dun Y, Zhi JM, Sun Hy, Zhao RR, Zhao ZQ. (2002) Activated polymorphonuclear leukocytes induce cardiomyocyte apoptosis and the protective effects of carvedilol. Methods Find Exp Clin Pharmacol 24, 403-12.

18. Yasunari K, Maeda K, Nakamura M, Watanabe T, Yoshikawa J, Asada A. (2005) Effect of carvedilol on oxidative stress in polymorphonuclear and mononuclear cells in patients with essential hypertension. Am J Med 118, 201-2.

19. Habon T, Szabados E, Kesmarsky G, Halmosi R, Past T, Sumegi B, Toth K. (2001) The effect of carvedilol on enhanced ADP-rybosila- tion and red blood cell membrane damage caused by free radicals. Acta Pharm Hung 71, 306-13.

20. Åsbrink S, Zickert A, Bratt J, Gyllenhammar H, Palmblad J. (2000) No effect of carvedilol on nitric oxide generation in phagocytes but modulation of production of superoxide ions. Biochem Pharmacol 59, 1007-13.

21. Suzuki Y, Tanaka M, Sohmiya M, Yoshida T, Okamoto K. (2003) Antioxidant properties of carvedilol: inhibition of lipid peroxidation, protein oxidation and superoxide generation.Neu- rol Res 25 , 749-53.

22. Gao F, Chen J, Lopez BL, Christopher TA, Gu J, Lysko P, Ruffolo RR Jr., Ohlstein EH, Ma XL, Yue TL. (1998) Comparison of bisoprolol and carvedilol cardioprotection in a rarbbit ischaemia and reperfusion model. Eur J Pharmacol 351, 341-50. 